\title{
Dosage of heparin for patency of the totally implanted central venous catheter in cancer patients
}

\author{
Francisca Jane Gomes de Oliveira ${ }^{1,2}$ \\ (D) https://orcid.org/0000-0002-4401-2009 \\ Andrea Bezerra Rodrigues ${ }^{3}$ \\ (1D) https://orcid.org/0000-0002-2137-0663 \\ Islane Costa Ramos ${ }^{4}$ \\ (1D) https://orcid.org/0000-0003-0048-8782 \\ Joselany Áfio Caetano 4 \\ (D) https://orcid.org/0000-0002-0807-056X
}

Universidade Federal do Ceará, Fortaleza, CE, Brazil.

2 Hospital Monte Klinikum, Unidade de Terapia Intensiva, Fortaleza, CE, Brazil.

${ }^{3}$ Hospital Universitário Walter Cantídio, Centro Cirúrgico, Fortaleza, CE, Brazil.

${ }^{4}$ Universidade Federal do Ceará, Departamento de Enfermagem, Fortaleza, CE, Brazil.
Objective: to analyze the evidence available in the literature about the lowest necessary dose of heparin to maintain the patency of the totally implanted central venous catheter in adult cancer patients. Method: an integrative literature review, carried out in the following databases: Literatura Latino-Americana e do Caribe em Ciências de Saúde, Sciverse Scopus, Web of Science, Cumulative Index to Nursing and Allied Health Literature, Cochrane Central Register of Controlled Trials, including thirteen studies. Results: the evidence showed that the dose of heparin (300 IU/ml) is the most used in maintaining the patency of the totally implanted central venous catheter. Conclusion: according to the selected studies, the lowest dose of heparin found in maintaining the patency of the totally implanted central venous catheter in cancer patients was $10 \mathrm{UN} / \mathrm{ml}$ with a volume of $5 \mathrm{ml}$ of the heparin solution.

Descriptors: Vascular Access Devices; Central Venous Catheters; Catheters, Indwelling; Heparin; Heparin Lock; Catheter Obstruction.

\section{How to cite this article}

Oliveira FJG, Rodrigues AB, Caetano JA, Ramos IC. Dosage of heparin for patency of the totally implanted central venous catheter in cancer patients. Rev. Latino-Am. Enfermagem. 2020;28:e3304. [Access † 千 — ] ; Available in: DOI: http://dx.doi.org/10.1590/1518-8345.3326.3304. month day year 


\section{Introduction}

Among the options of devices used for the longterm administration of chemotherapy in cancer patients is the totally implanted central venous catheter (CVC-TI), such as the port-a-cath ${ }^{\circledR}$, a siliconized rubber device, surgically implanted, which has a reservoir located at the distal end, which remains below the skin in the thoracic region, on a bone surface ${ }^{(1)}$.

The CVC-TI offers greater comfort to the patient and a lower infection rate, reduces the risk of thrombosis, allows for outpatient treatment, does not interfere in the patient's daily activities, and preserves the peripheral venous system, in addition to reducing the suffering and stress of the patients by avoiding repeated unsuccessful venous punctures, when compared to other available catheters ${ }^{(2)}$.

Although widely used, this device is not exempt from complications, such as hematomas, gas embolism, complications resulting from the anesthetic act, cardiac tamponade, and intolerance to the catheter. And because it is a long-term catheter, late complications are also added, such as: thrombosis, infection, catheter migration, rupture or fracture of the system, and catheter occlusion, among others ${ }^{(3)}$.

Occlusion of a CVC-TI is defined as the inability to infuse and/or draw blood from it, which can be classified as thrombotic, mechanical or chemical, being an event of concern for the health team, as it is mostly related to suspension of therapy or even exposure of the patient to a new invasive procedure(4-5).

The Occlusion Management Guideline for Central Venous Access Devices (CVADs) guideline, whose purpose is to standardize the care related to the clinical practice in order to obtain positive results with a CVC-TI, considers the health professional fundamental for the management, prevention, and treatment of the occlusion, as this is the main responsible for its direct handling(6).

Thus, in order to reduce complications related to this device, its handling, maintenance and optimization can be understood as a set of practices in which the nurse must gather knowledge, skills and attitudes that enable him to ensure an appropriate handling of them.

To guarantee CVC-TI patency, some precautions are necessary such as using the appropriate solution and performing the correct washing and blocking technique of this device, according to available protocols and guidelines, thus preventing its occlusion ${ }^{(4,7)}$.

A qualitative study on nurses' knowledge related to the maintenance of the CVC-TI pointed out that one of the most frequent doubts refers to the ideal dose of heparin to maintain the patency of the device, and the time between each dose, when the catheter is not in continuous use. This corroborates the opinion of the authors, who state that, although there are several guidelines and rules related to this context, when addressing the solution and suggested dose to maintain CVC-TI patency, doubts still remain, as there are several practices in use in the clinical setting (saline solution, heparin, sodium citrate, among other chemical solutions)(8-10).

Over the years, the heparinized solution has been the most used method to maintain the patency of the catheter; however, the routine of this technique seems to hide the iatrogenic effects of the drug itself, such as thrombocytopenia, which occurs due to its connection with an inhibitor of serine protease, antithrombin (AT), causing conformational change in the AT molecule, resulting in increased inhibition of thrombin (factor IIa) and of other serine proteases involved in the coagulation cascade. As thrombin stimulates the conversion of fibrinogen to fibrin, being inhibited, consequently, it generates a decrease in the formation of fibrin ${ }^{(11)}$.

Because it is an anticoagulant that acts at the level of the coagulation cascade and contributes to the development of adverse events, even if used in small quantities, such as washing (flush) of central venous catheters, it affects up to 20 to $30 \%$ of the patients who are exposed to the drug ${ }^{(12-13)}$. In this context, the objective of this study is to analyze scientific evidence in the literature on the lowest necessary dose of heparin to maintain the patency of the totally implanted central venous catheter in adult cancer patients.

\section{Method}

This is an integrative literature review study, which allows for research studies already carried out to be summarized and conclusions to be established based on the critical evaluation of different methodological approaches, aiming to synthesize and analyze the data to develop a more comprehensive explanation of a specific phenomenon from the synthesis or analysis of study findings, with theoretical and/or interventionist purposes ${ }^{(14)}$.

Thus, six stages were adopted for the elaboration of this review: selection of the research question; definition of study inclusion criteria and sample selection; representation of the selected studies in table format, considering all the characteristics in common; critical analysis of the findings, identifying differences and conflicts; interpretation of the results, and clearly reporting the evidence found ${ }^{(15)}$.

For the elaboration of the guiding question, the PICOS strategy was used, with P for Population, Patient 
or Problem (adult cancer patients with totally implanted central venous catheter), I for Intervention or area of Interest (heparin dose used in the maintenance of the CVC-TI), C for Comparison (heparin dose used to maintain the CVC-TI), O for Outcomes (maintenance of CVC-TI patency) and S for the type of Studies used (systematic reviews of controlled and randomized clinical trials, controlled and randomized clinical trials, systematic review of cohort studies, and cohort studies) (16). Thus, this study sought to answer the following question: What evidence is available in the literature about the lowest necessary dose of heparin to maintain the patency of the totally implanted central venous catheter in adult cancer patients?

As an inclusion criterion, studies published in English, Spanish or Portuguese were chosen, which included the thematic use of heparin to maintain the CVC-TI in adult cancer patients, such as systematic reviews of controlled and randomized clinical trials, controlled and randomized clinical trials, systematic review of cohort studies, and cohort studies.

This criterion was established as a result of the answer to be obtained in relation to the guiding question of the study, in which it was sought to follow the classification of level of evidence proposed by the Oxford Centre for Evidence-Based Medicine, where the levels of evidence are classified as follows: 1A - systematic review (with homogeneity) of controlled and randomized clinical trials, $1 B$ - controlled and randomized clinical trial with a narrow confidence interval, $1 \mathrm{C}$ - all-or-nothing therapeutic results, $2 \mathrm{~A}$ - systematic review of cohort studies, $2 \mathrm{~B}$ - cohort study, 2C - observational study, $3 \mathrm{~A}$ - systematic review (with homogeneity) of case-control studies, 3B - case-control study, 4 - lower quality case series and cohort studies, and 5 - specialists' opinion devoid of critical assessment, based on consensus, physiological studies ${ }^{(17)}$.

The search for the studies was carried out during the months of August and September 2018, in the following databases: Latin American and Caribbean Health Sciences Literature (Literatura Latino-Americana e do Caribe em Ciências de Saúde, LILACS), SCOPUS, Web of Science, Cumulative Index to Nursing and Allied Health Literature (CINAHL), and Cochrane Central Register of Controlled Trials (COCHRANE).

For the selection of the articles, a consultation was first made with the Health Science Descriptors (Descritores em Ciência da Saúde, DeCS) and the Medical Subject Headings (MeSH), in all the databases, with the following descriptors and their synonyms being identified and used with the use of the OR Boolean operator (MESH): "catheters, indwelling" OR "vascular access devices" OR "port catheters" OR "port a cath" OR "catheters, port" OR "port, vascular access" OR "vascular access port" OR "central venous catheters" OR "totally implantable venous device" OR "totally implantable central venous access port" OR heparin OR "heparin lock" OR "heparin flush" OR "obstruction catheter" OR "catheter obstruction". Most of the descriptors were enclosed in quotation marks because they are compound terms.

After searching the databases, all the studies were sent to the EndNote $X 8$ reference manager, where filtering was performed to exclude duplicate articles, being considered only once. Then, all the titles were read, and then the abstracts. After the final selection, the articles were read in full in order to select those who answered the guiding question of the research. After this process, publications that did not comply with the purpose of the study were excluded.

For the synthesis of the selected articles, an instrument was used that contemplates the following items: name of the article, authors, year of publication, level of evidence, objective, method, methodological quality and results, with the purpose of extracting, organizing and summarizing the information and facilitating the formation of the database.

Regarding the evaluation of the methodological quality of the randomized clinical trials, the scale proposed by Jadad, et al. $(1996)^{(18)}$ was used. This scale consists of five criteria and varies from 0 to 5 points, where each item receives 1 point for the "yes" answer, or zero points for the "no" answer, in which a score below 3 indicates that the study has a low methodological quality and that its results can hardly be extrapolated to other scenarios.

The systematic reviews were assessed according to the Assessment of Multiple Systematic Reviews (AMSTAR). AMSTAR was built from the analysis and updating of other empirically validated instruments ${ }^{(19)}$. The items that comprise the checklist present minimum requirements for a systematic review: The review design was presented a priori? Was there duplication in data extraction and study selection? Was a comprehensive search of the databases carried out? Was the status of the publication (e.g., theses and dissertations, book chapters, etc.) used as an inclusion criterion? Has a list of included and excluded studies been provided? Were the characteristics of the included studies provided? Has the quality of the included studies been assessed and documented? Has the quality of the included studies been used appropriately in the conclusions? Were the methods used to group the findings of the included studies appropriate? Has publication bias been assessed? Has the conflict of interest been described? For each item of the instrument there are two answer options: a) "yes", if the review explicitly contemplates the criterion; b) "no", if it does 
not. For each "yes" answer, one point ${ }^{(20)}$ is applied. The more items in accordance with the checklist, the better the methodological quality of the study. The calculation of the final score was converted into a percentage and the quality of the manuscripts was assessed in three categories for both criteria: A for studies that meet more than $80 \%$ of the criteria established by Strengthening the Reporting of Observational Studies in Epidemiology (STROBE); B for studies that meet $50 \%$ to $80 \%$ of these criteria; and C for studies that meet less than $50 \%$ of the criteria(21).

The STROBE guidelines were used to assess the observational studies, in which a score of 0 means "does not meet" and a score of 1 means "meets", being used for each of the 22 items of the STROBE guidelines. As well as in AMSTAR, the calculation of the final score was converted into a percentage and the quality of the manuscripts was assessed in three categories for both criteria: A for studies that meet more than $80 \%$ of the criteria established by STROBE; B for studies that meet
$50 \%$ to $80 \%$ of these criteria; and $\mathrm{C}$ for studies that meet less than $50 \%$ of the criteria(21).

Independently, two researchers carried out the selection of studies: first, studies were excluded from the reading of their titles (first analysis), then abstracts (second analysis) and, finally, after reading the full texts (third analysis). In case of disagreement or doubt, a third experienced researcher was consulted.

The discussion of the obtained data was carried out in a descriptive way, allowing the reader to evaluate the applicability of the integrative review elaborated, in order to achieve the objective of this method, that is, to facilitate the incorporation of evidence and build knowledge in the area of higher education in Nursing.

\section{Results}

At the end of the article search process, the sample of the integrative review was composed of 13 primary studies, as shown in Figure 1.

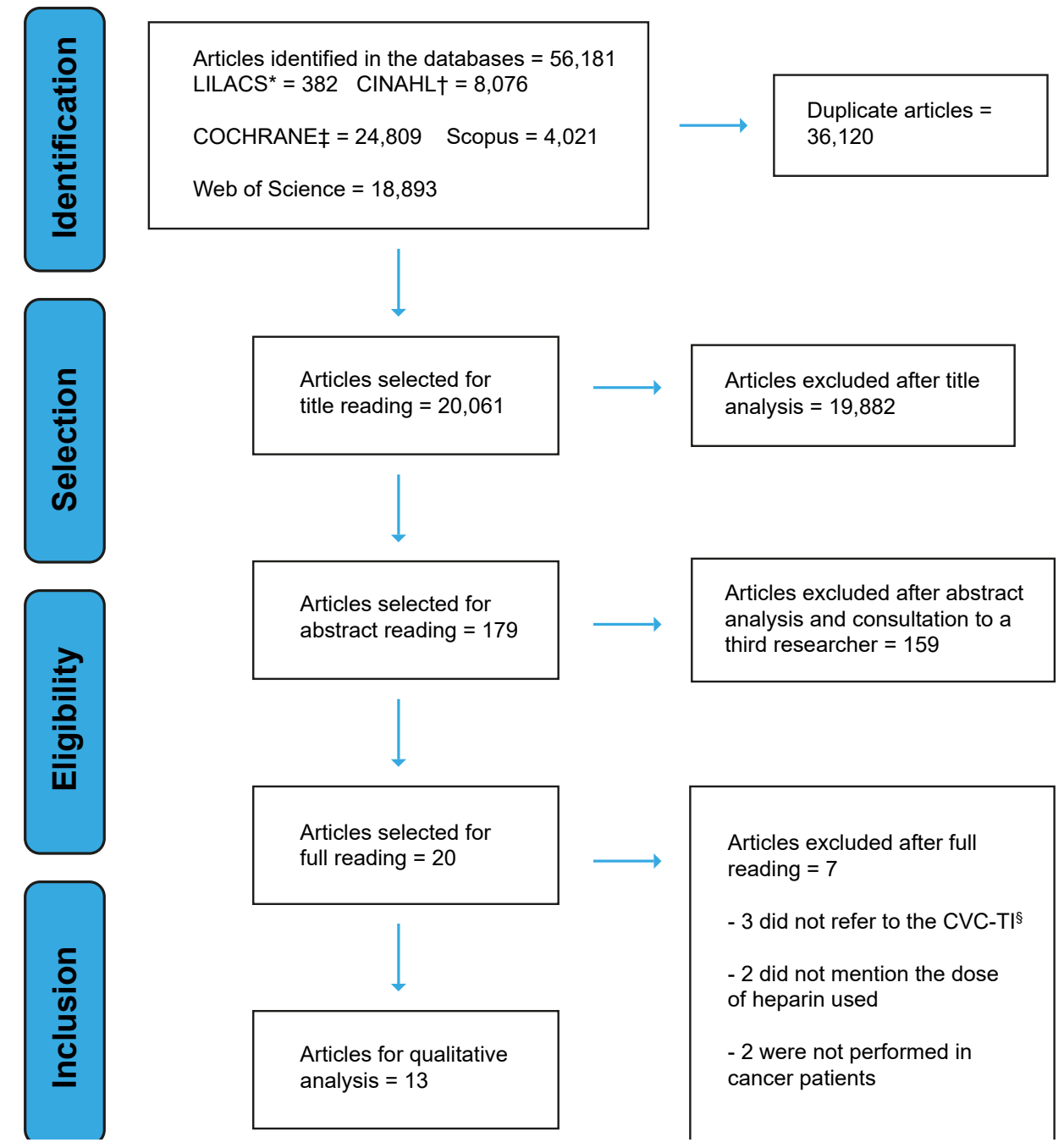

*LILACS = Literatura Latino-Americana e do Caribe em Ciências de Saúde $;{ }^{+}$CINAHL = Cumulative Index to Nursing and Allied Health Literature; ${ }^{\ddagger}$ COCHRANE $=$ Cochrane Central Register of Controlled Trials, ${ }^{\circledR}$ CVC-TI $=$ Totally Implanted Central Venous Catheter

Figure 1 - Flowchart of the selection process for the primary studies. Fortaleza, CE, Brazil, 2018 
Of the 13 selected articles, 11 were considered of high methodological quality, and two of medium methodological quality, according to the adopted criteria. The E07 article was evaluated with medium methodological quality, for meeting $6 / 11$ evaluated items (55\%), and the E09 study with high methodological quality for meeting $11 / 11$ evaluated items (100\%).

As for the characteristics of the methodological designs, seven were cohort studies (E01, E03, E05, E06, E07, E10 and E12), four randomized clinical trials (E02, E04, E11, and E13) and two systematic reviews (E08, E09).

With regard to the study site, two were developed in the United States of America (E01, E06), four in Italy (E02, E5, E10, E13), two in Belgium (E4, E8), one in Brazil (E03), one in Iraq (E07), one in the United Kingdom (E09), one in Sweden (E11) and one in Istanbul (E12). The characteristics of the studies, with regard to the identification code, authors, title and level of evidence, are represented in Figure 2.

\begin{tabular}{|c|c|c|c|}
\hline Study code/Author(s)/ Year & Title & $\begin{array}{c}\text { Evidence } \\
\text { level }\end{array}$ & $\begin{array}{l}\text { Methodological } \\
\text { quality }\end{array}$ \\
\hline $\begin{array}{l}\text { E01. Girda E; Phaeton R; Nevadunsky N; } \\
\text { Huang G; Smith Ho; Smotkin D; Goldberg } \\
\text { G; Kuo D, } 2013^{(1)} \text {. }\end{array}$ & Extending the interval for port-a-cath maintenance & $2 \mathrm{~B}^{*}$ & Category $\mathrm{A}^{\S}$ \\
\hline $\begin{array}{l}\text { E02. Dal Molin A, Clerico M, Baccini M, } \\
\text { Guerretta L, Sartorello B, } \\
\text { Rasero L, } 2015^{(22)} \text {. }\end{array}$ & $\begin{array}{l}\text { Normal saline versus heparin solution to lock totally implanted venous } \\
\text { access devices: Results from a multicenter randomized trial }\end{array}$ & $1 \mathrm{~B}^{\dagger}$ & High quality \\
\hline E03. Brito, $2018^{(23)}$. & $\begin{array}{l}\text { Comparison between Saline Solution Containing Heparin versus Saline } \\
\text { Solution in the Lock of Totally Implantable Catheters }\end{array}$ & $2 \mathrm{~B}^{*}$ & Category $\mathrm{A}^{\S}$ \\
\hline $\begin{array}{l}\text { E04. Goossens GA; Jérôme M; } \\
\text { Janssens C; Peetermans WE; Fieuws S; } \\
\text { Moons P; Verschakelen J; Peerlinck K; } \\
\text { Jacquemin M; Stas M, 2013(24). }\end{array}$ & $\begin{array}{l}\text { Comparing normal saline versus diluted heparin to lock non-valved } \\
\text { totally implantable venous access devices in cancer patients: a } \\
\text { randomised, non-inferiority, open trial }\end{array}$ & $1 \mathrm{~B}^{\dagger}$ & High quality \\
\hline $\begin{array}{l}\text { E05. Bertoglio S, Solari N, Meszaros } \\
\text { P, Vassallo F, Bonvento M, Pastorino } \\
\text { S, Bruzzi P, } 2012^{(25)}\end{array}$ & $\begin{array}{l}\text { Efficacy of normal saline versus heparinized saline solution for locking } \\
\text { catheters of totally implantable long-term central vascular access } \\
\text { devices in adult cancer patients }\end{array}$ & $2 \mathrm{~B}^{*}$ & Category $\mathrm{A}^{\S}$ \\
\hline $\begin{array}{l}\text { E06. Kuo YS; Schwartz B; Santiago J; } \\
\text { Anderson PS; Fields AL; } \\
\text { Goldberg GL, } 2005^{(26)} \text {. }\end{array}$ & How Often Should a Port-A-Cath be Flushed? & $2 \mathrm{~B}^{*}$ & Category B\| \\
\hline $\begin{array}{l}\text { E07. Baram A, Majeed G, Abdullah H, } \\
\text { Subhi A, 2014(27). }\end{array}$ & $\begin{array}{l}\text { Heparin versus Saline Solution for Locking of Totally Implantable } \\
\text { Venous Access Port (TIVAP): Cohort Study of the First Kurdistan } \\
\text { Series of TIVAP }\end{array}$ & $2 \mathrm{~B}^{*}$ & Category $\mathrm{A}^{\S}$ \\
\hline E08. Goossens GA, 2014 ${ }^{(28)}$. & $\begin{array}{l}\text { Flushing and Locking of Venous Catheters: Available Evidence and } \\
\text { Evidence Deficit }\end{array}$ & $1 A^{\ddagger}$ & Medium quality \\
\hline $\begin{array}{l}\text { E09. López-Briz E, Ruiz GV, Cabello } \\
\text { JB, Bort-Marti S, Carbonell SR, Burls A, } \\
\text { 2014 } \\
\end{array}$ & $\begin{array}{l}\text { Heparin versus } 0.9 \% \text { sodium chloride intermittent flushing for } \\
\text { prevention of occlusion in central venous catheters in adults }\end{array}$ & $1 A^{\ddagger}$ & High quality \\
\hline $\begin{array}{l}\text { E10. Palese A, Baldassar D, Rupil A } \\
\text { et al. } 2014^{(3)} \text {. }\end{array}$ & $\begin{array}{l}\text { Maintaining patency in totally implantable venous access devices } \\
\text { (TIVAD): A time-to-event analysis of different lock irrigation intervals }\end{array}$ & $2 \mathrm{~B}^{*}$ & Category $\mathrm{A}^{\S}$ \\
\hline $\begin{array}{l}\text { E11. Johansson E, Björkholm M, Björvell } \\
\text { H et al. } 2004^{(30)} \text {. }\end{array}$ & $\begin{array}{l}\text { Totally implantable subcutaneous port system versus central venous } \\
\text { catheter placed before induction chemotherapy in patients with acute } \\
\text { leukaemia-a randomized study }\end{array}$ & $1 \mathrm{~B}^{\dagger}$ & High quality \\
\hline $\begin{array}{l}\text { E12. Kefeli U, Dane F, Yumuk PF, } \\
\text { et al. 2009(31). }\end{array}$ & $\begin{array}{l}\text { Prolonged interval in prophylactic heparin flushing for maintenance of } \\
\text { subcutaneous implanted port care in patients with cancer }\end{array}$ & $2 \mathrm{~B}^{*}$ & Category $\mathrm{A}^{\S}$ \\
\hline $\begin{array}{l}\text { E13. Biffi R, Braud F, Orsi F } \\
\text { et al. 2001 }\end{array}$ & $\begin{array}{l}\text { A randomized, prospective trial of central venous ports connected to } \\
\text { standard open-ended or Groshong catheters in adult oncology patients }\end{array}$ & $1 \mathrm{~B}^{\dagger}$ & High quality \\
\hline
\end{tabular}

Classification of the level of evidence of the studies according to the Oxford Center for Evidence-Based Medicine: ${ }^{*} \mathrm{~B}=$ cohort $^{2}$ studies; ${ }^{+} 1 \mathrm{~B}=\mathrm{studies}$ of controlled and randomized clinical trial with a narrow confidence interval; ${ }^{\ddagger} 1^{\text {st }}=$ systematic review studies (with homogeneity) of controlled and randomized clinical trials. Evaluation of the methodological quality: ${ }^{5}$ Category $\mathrm{A}=$ studies evaluated according to the criteria of the Strengthening the Reporting of Observational Studies in Epidemiology (STROBE) of the Assessment of Multiple Systematic Reviews (AMSTAR) and that met more than $80 \%$ of the established criteria; "Category B = studies evaluated according to the criteria of the Strengthening the Reporting of Observational Studies in Epidemiology (STROBE) or the Assessment of Multiple Systematic Reviews (AMSTAR) and that met $50 \%$ to $80 \%$ of these criteria

Figure 2 - Distribution of the primary studies according to author, title, level of evidence and methodological quality. Fortaleza, CE, Brazil, 2018

Regarding the objectives of the studies, five evaluated the efficacy of the saline solution compared to heparin to maintain the patency of the catheter (E02, E03, E04, E05, E07, E09), five sought to know a longer interval for maintaining the CVCTI (E01, E06, E10, E11, E12), two compared the effectiveness of the catheters and their complications in cancer patients (E11, E13) and one evaluated flushs and locks for maintaining CVC-TI patency (E08). Figure 3 shows the description of the articles selected for the study, with regard to the objective, intervention and results. 


\begin{tabular}{|c|c|c|}
\hline Objective & Intervention/Maintenance & Result \\
\hline $\begin{array}{l}\text { E01. To standardize a safe and } \\
\text { adequate interval to maintain CVC-TI } \\
\text { patency }{ }^{*} \text {. }\end{array}$ & $\begin{array}{l}\text { The protocol used a } 10 \mathrm{ml} \text { flush }{ }^{\dagger} \text { of physiological serum } \\
\text { followed by a } 5 \mathrm{ml} \text { heparin lock }\left(100 \mathrm{IU} / \mathrm{ml}^{\ddagger}\right) \text {. } \\
\text { Total number of patients included: } 201 .\end{array}$ & $\begin{array}{l}\text { When compared to } 90 \text {-day maintenance versus } \\
\text { those more than } 90 \text { days apart (mean of } \\
112 \text { days), there was no difference in occlusion } \\
\text { rates between the groups. }\end{array}$ \\
\hline $\begin{array}{l}\text { E02. To determine the effectiveness } \\
\text { of the saline solution compared } \\
\text { to heparin in maintaining totally } \\
\text { implanted venous access devices. }\end{array}$ & $\begin{array}{l}\text { Saline Solution Group (203 patients): flush with } 20 \mathrm{ml}^{\dagger} \text { saline } \\
\text { solution, followed by a block with } 5 \mathrm{ml}^{\dagger} \text { saline solution, using } \\
\text { positive pressure. } \\
\text { Heparin Group ( } 212 \text { patients): wash with } 10 \mathrm{ml}^{\dagger} \text { saline } \\
\text { solution followed by a block with } 5 \mathrm{ml}^{\dagger} \text { heparin }\left(10 \mathrm{IU} / \mathrm{ml}^{\ddagger}\right) \text {. }\end{array}$ & $\begin{array}{l}\text { CVC-TI* occlusions were observed in } \\
24 \text { patients: } 10(4.71 \%) \text { in heparin and } \\
14(6.90 \%) \text { in the normal saline group, with no } \\
\text { significant difference in the results. }\end{array}$ \\
\hline $\begin{array}{l}\text { E03. To compare the heparinized } \\
\text { saline solution versus } 0.9 \% \text { saline } \\
\text { solution for the maintenance of } \\
\text { CVC-TI*. }\end{array}$ & $\begin{array}{l}\text { Heparin Group ( } 270 \text { patients): maintenance consisting of } \\
1.5 \mathrm{ml}^{\dagger} \text { of } 0.9 \% \text { saline solution with heparin content }\left(100 \mathrm{IU} / \mathrm{ml}^{\ddagger}\right) . \\
\text { Saline Solution Group (592 patients): maintenance with } 1.5 \\
\mathrm{ml}^{\dagger} \text { of } 0.9 \% \text { saline solution. }\end{array}$ & $\begin{array}{l}\text { Regarding CVC-TI* occlusion, there were } \\
8 \text { cases in the Heparin group and } 8 \text { cases in } \\
\text { the Saline Solution group, with no statistical } \\
\text { difference between the groups. }\end{array}$ \\
\hline $\begin{array}{l}\text { E04. To evaluate the effectiveness } \\
\text { of heparin compared to the saline } \\
\text { solution. }\end{array}$ & $\begin{array}{l}\text { Saline Solution Group ( } 404 \text { patients): wash with } 10 \mathrm{ml}^{\dagger} \text { saline } \\
\text { solution before and after blood collection and drug } \\
\text { administration, every } 8 \text { weeks, when the device was not in } \\
\text { use and with } 20 \mathrm{ml}^{\dagger} \text { saline solution after administration of } \\
\text { blood (components) or parenteral nutrition. } \\
\text { Heparin Group ( } 398 \text { patients): block with } 3 \mathrm{ml}^{\dagger} \text { heparin before } \\
\text { the needle is removed. }\end{array}$ & $\begin{array}{l}\text { No significant complications were found when } \\
\text { using saline solution instead of heparin as a } \\
\text { blocking solution for catheter maintenance. }\end{array}$ \\
\hline $\begin{array}{l}\text { E05. To evaluate the efficacy and } \\
\text { safety of the normal saline solution } \\
\text { for CVC-TI blocking procedures*. }\end{array}$ & $\begin{array}{l}\text { Heparin Group ( } 297 \text { patients): wash with heparinized } \\
\text { solution ( } 500 \mathrm{IU} / 10 \mathrm{ml}^{\ddagger} \text { ) } \\
\text { Saline Solution Group (313 patients): } 10 \mathrm{ml}^{\dagger} \text { normal saline } \\
\text { solution. }\end{array}$ & $\begin{array}{l}\text { The results do not show statistically significant } \\
\text { differences with regard to catheter obstruction. }\end{array}$ \\
\hline $\begin{array}{l}\text { E06. To demonstrate that a longer } \\
\text { maintenance interval for CVC-TI* } \\
\text { can be safe, convenient, and more } \\
\text { efficient. }\end{array}$ & $\begin{array}{l}\text { Washing the catheter with } 10 \mathrm{ml}^{\dagger} \text { saline solution followed } \\
\text { by a block with } 5 \mathrm{ml}^{+} \text {heparin }\left(100 \mathrm{IU} / \mathrm{ml}^{\ddagger}\right) \text {. Total number of } \\
\text { patients included: } 82 \text {. }\end{array}$ & $\begin{array}{l}\text { The mean intervals for catheter maintenance } \\
\text { ranged from } 38 \text { to } 244 \text { days, with a mean } \\
\text { interval between patients without complications } \\
\text { associated with catheter obstruction of } 63 \text { days. }\end{array}$ \\
\hline $\begin{array}{l}\text { E07. To evaluate the efficacy and } \\
\text { safety of the normal saline solution in } \\
\text { the practice of maintaining CVC-TI* } \\
\text { in cancer patients }\end{array}$ & $\begin{array}{l}\text { Heparin Group (194 patients): wash twice a month with } \\
\text { heparinized solution ( } 20 \mathrm{ml}^{\dagger} \text { normal saline solution and } \\
5,000 \mathrm{IU} / \mathrm{ml}^{\ddagger} \text { unfractionated heparin). } \\
\text { Saline Solution Group (190 patients): wash the catheter with } \\
20 \mathrm{ml}^{\dagger} \text { saline solution twice a month. }\end{array}$ & $\begin{array}{l}\text { The incidence of catheter-related occlusion was } \\
\text { quite low for both groups, with no significant } \\
\text { differences between the two groups. }\end{array}$ \\
\hline $\begin{array}{l}\text { E08. To clarify issues related to } \\
\text { washing and blocking the CVC- } \\
\text { TIs* and to describe the available } \\
\text { evidence regarding the benefits } \\
\text { of the interventions in relation to } \\
\text { occlusion. }\end{array}$ & Washing and blocking venous catheters. & $\begin{array}{l}\text { For washing the catheter a volume of } \\
10 \mathrm{ml}^{\dagger} \text { saline solution is sufficient. Regarding the } \\
\text { block, volumes should be minimal and based } \\
\text { on the prime of the catheter. A maximum of } \\
1 \mathrm{ml}^{\dagger} \text { excess volume for the block is adequate to } \\
\text { safely fill the catheter and any complements. }\end{array}$ \\
\hline $\begin{array}{l}\text { E09. To evaluate the effectiveness of } \\
\text { washing with heparin versus saline } \\
\text { solution in adults with central venous } \\
\text { catheters. }\end{array}$ & Heparin x saline solution. & $\begin{array}{l}\text { The review found no convincing evidence of a } \\
\text { reduction in the CVC§ occlusion rate maintained } \\
\text { with heparin compared to CVC§ maintained } \\
\text { with sterile saline solution. As heparin is more } \\
\text { expensive, the results of this review do not } \\
\text { support its use, except in future clinical trials. }\end{array}$ \\
\hline $\begin{array}{l}\text { E10. To evaluate the efficacy of } \\
\text { irrigating CVC-TI* devices every } \\
\text { eight weeks, instead of every } \\
\text { four weeks, to maintain the patency } \\
\text { of the device. }\end{array}$ & $\begin{array}{l}\text { A wash with } 20 \mathrm{ml}^{\dagger} \text { normal saline solution, followed } \\
\text { by a block with } 3 \mathrm{ml}^{\dagger} \text { sodium heparin }\left(250 \mathrm{IU} / 5 \mathrm{ml}^{\ddagger}\right) \\
\text { for a total of } 150 \text { units of heparin was performed with } \\
\text { two homogeneous groups with catheter maintenance every } \\
4 \text { weeks ( } 17 \text { patients) and } 8 \text { weeks ( } 20 \text { patients). }\end{array}$ & $\begin{array}{l}\text { There were no differences in the occurrence } \\
\text { of occlusion between CVC-TIs* irrigated every } \\
\text { four weeks, instead of every eight weeks. }\end{array}$ \\
\hline $\begin{array}{l}\text { E11. To compare the survival time, } \\
\text { function, and complication rates of } \\
\text { double lumen CVC }{ }^{\S} \text { use versus CVC- } \\
\text { II* for chemotherapy in patients with }_{\text {leukemia. }}\end{array}$ & $\begin{array}{l}\text { CVC-TI Group* }\left(19 \text { patients): wash with } 5 \mathrm{ml}^{\dagger} \text { heparinized }\right. \\
\text { saline solution }\left(100 \mathrm{IU} / \mathrm{ml}^{\ddagger}\right) \text { after each use or at least once a } \\
\text { month. } \\
\text { Double lumen } \mathrm{CVC}^{\S}(24 \text { patients): wash with } \\
5 \mathrm{ml}^{\dagger} \text { heparinized saline solution }\left(12.5 \mathrm{IU} / \mathrm{ml}^{\ddagger}\right) \text { after use and } \\
\text { at least twice a week. }\end{array}$ & $\begin{array}{l}\text { There was no significant difference between the } \\
\text { two groups regarding the catheter survival time. } \\
\text { CVC } \$ \text { occlusion was noted on } 14 \text { occasions } \\
\text { in seven patients; and CVC-TI* occlusion, in } \\
3 \text { patients. }\end{array}$ \\
\hline $\begin{array}{l}\text { E12. To compare the safety and } \\
\text { efficacy of administering a larger } \\
\text { dose of heparin }\left(1,000 \mathrm{IU} / \mathrm{ml}^{\ddagger}\right) \text { and } \\
\text { flushes every } 6 \text { weeks, versus } \\
\text { standard dose and schedule (500 IU/ } \\
\mathrm{ml}^{\ddagger} \text { every } 4 \text { weeks), to reduce } \\
\text { the incidence of CVC-TI*-related } \\
\text { infections and thrombosis. }\end{array}$ & $\begin{array}{l}\text { For catheter maintenance after chemotherapy. } \\
\text { Group } 1 \text { ( } 59 \text { patients): they received } 1,000 \mathrm{IU} / \mathrm{ml}^{\ddagger} \text { heparin in } \\
3 \mathrm{ml}^{\dagger} \text { normal saline solution every } 6 \text { weeks. } \\
\text { Group } 2\left(30 \text { patients): they received } 500 \mathrm{IU} / \mathrm{ml}^{\ddagger} \text { heparin in } 3.5\right. \\
\mathrm{ml}^{\dagger} \text { normal saline solution every } 4 \text { weeks. }\end{array}$ & $\begin{array}{l}\text { Maintaining catheter patency with } 1,000 \mathrm{IU} / \\
\mathrm{ml}^{\ddagger} \text { heparin every } 6 \text { weeks may be a safer, } \\
\text { easier, more economical, comfortable and } \\
\text { effective alternative when compared to standard } \\
4 \text {-week administration to prevent thrombosis and } \\
\text { infections. }\end{array}$ \\
\hline $\begin{array}{l}\text { E13. To compare the associated } \\
\text { complications in patients with } \\
\text { Groshong catheter and CVC-TI* } \\
\text { in cancer patients undergoing } \\
\text { chemotherapy. }\end{array}$ & $\begin{array}{l}\text { Both the control (152 patients with Groshong catheter) and } \\
\text { the intervention }(152 \text { patients with CVC-TI*) groups received } \\
5 \mathrm{ml}^{+} \text {heparin }\left(50 \mathrm{IU} / \mathrm{ml}^{\ddagger}\right) \text { for catheter maintenance every } \\
28 \text { days. }\end{array}$ & $\begin{array}{l}\text { It has been shown that the Groshong central } \\
\text { venous catheter (at least when used for the } \\
\text { administration of long-term chemotherapy) is } \\
\text { not superior to CVC-TI* in terms of early and } \\
\text { late complications. With regard to catheter } \\
\text { obstruction, there was no difference between } \\
\text { the two. }\end{array}$ \\
\hline
\end{tabular}

${ }^{*} \mathrm{CVC}-\mathrm{TI}=$ Totally Implanted Central Venous Catheter; ${ }^{+} \mathrm{ml}=$ Milliliters; $<^{\ddagger}=$ International units per milliliter; ${ }^{\S} \mathrm{CVC}=\mathrm{Central}$ Venous Catheter

Figure 3 - Synthesis of the primary articles according to the objective, intervention and results. Fortaleza, CE, Brazil, 2018 
Regarding the concentration and volume of heparin used to maintain CVC-TI patency, seven studies (E01, E03, E04, E06, E08, E09, E11) used a heparin concentration of $100 \mathrm{IU} / \mathrm{ml}$ with the administered volume ranging between 3 and $5 \mathrm{ml}$. Higher concentrations of heparin (500 IU/ml, 5,000 IU/ml, $250 \mathrm{IU} / \mathrm{ml}$ and $1,000 \mathrm{IU} / \mathrm{ml}$ ) were identified in studies E05, E07, E10, and E12 which, when compared to the saline solution for CVC-TI maintenance, and either this procedure was performed with an interval of 15 to 20 days (E07, E02), 28 days (E03, E05, E09, E11, E13) or with intervals longer than 56 to 90 days (E04, E08, E01, E10, E12), no significant differences were identified with regard to obstruction or other complications associated with the catheter. Figure 4 shows the concentrations and volume of heparin used in studies for maintaining CVC-TI and the interval between the applications.

\begin{tabular}{|c|c|c|c|c|}
\hline Studies & Heparin concentration $\left(\mathrm{IU} / \mathrm{ml}^{*}\right)$ & Heparin volume & Total heparin concentration & Maintenance interval \\
\hline E 01 & $100 \mathrm{IU} / \mathrm{ml}^{*}$ & $5 \mathrm{ml}^{+}$ & $500 \mathrm{IU} \S$ & 90 days \\
\hline E 02 & $10 \mathrm{IU} / \mathrm{ml}^{*}$ & $5 \mathrm{ml}^{+}$ & $50 \mathrm{IU} \S$ & 20 days \\
\hline E 03 & $100 \mathrm{IU} / \mathrm{ml}^{*}$ & $1.5 \mathrm{ml}^{\dagger}$ & $150 I U^{\S}$ & 28 days \\
\hline E 04 & $100 \mathrm{IU} / \mathrm{ml}^{*}$ & $3 \mathrm{ml}^{+}$ & $300 \mathrm{IU}$ & 56 days \\
\hline E 05 & $500 \mathrm{IU} / \mathrm{ml}^{*}$ & $10 \mathrm{ml}^{\dagger}$ of the solution ${ }^{\ddagger}$ & $500 \mathrm{IU} s$ & 28 days \\
\hline E 06 & $100 \mathrm{IU} / \mathrm{ml}^{*}$ & $5 \mathrm{ml}^{\dagger}$ & $500 \mathrm{IU} \S$ & 38 days \\
\hline E 07 & $5000 \mathrm{IU} / \mathrm{ml}^{*}$ & $20 \mathrm{ml}^{\dagger}$ of the solution ${ }^{\ddagger}$ & $5000 \mathrm{IU} s$ & 15 days \\
\hline E 08 & $100 \mathrm{IU} / \mathrm{ml}^{*}$ & $2.5 \mathrm{ml}^{\dagger}$ & $250 \mathrm{IU}$ & $42-56$ days \\
\hline E 09 & $100 \mathrm{IU} / \mathrm{ml}^{*}$ & $3 \mathrm{ml}^{\dagger}$ & $300 \mathrm{IU} s$ & 28 days \\
\hline E 10 & $250 \mathrm{lU} / 5 \mathrm{ml}^{*}$ & $3 \mathrm{ml}^{+}$ & 750 IUS & $28-56$ days \\
\hline E 11 & $100 \mathrm{IU} / \mathrm{ml}^{*}$ & $5 \mathrm{ml}^{+}$ & $500 \mathrm{IU} \S$ & 28 days \\
\hline E 12 & $1,000 \mathrm{IU} / \mathrm{ml}^{*}$ and $500 \mathrm{IU} / \mathrm{ml}^{*}$ & $3 \mathrm{ml}^{+}$and $3.5 \mathrm{ml}^{+}$ & $\begin{array}{c}3000 \mathrm{IU} \\
\text { and } 1,750 \mathrm{IU}\end{array}$ & 28 and 42 days \\
\hline E 13 & $50 \mathrm{IU} / \mathrm{ml}^{*}$ & $5 \mathrm{ml}^{+}$ & 250 IU§ & 28 days \\
\hline
\end{tabular}

$* \mathrm{IU} / \mathrm{ml}=$ International units per milliliter; ${ }^{+} \mathrm{ml}=$ Milliliters; ${ }^{\ddagger}$ solution = Solution composed of the heparin concentration reported in the table, combined with this quoted volume of saline solution; ${ }^{\S} \mathrm{IU}=$ International units

Figure 4 - Synthesis of the studies according to concentration/ml, volume, total heparin concentration, and maintenance interval. Fortaleza, CE, Brazil, 2018

\section{Discussion}

Obstruction of the CVC-TI results in suspension of treatment, increased risks and related costs, making it a relevant concern for the health professionals. Therefore, measures to reduce this problem are of crucial importance, especially with regard to the choice of the solution and the dose to be used to maintain the patency of the device ${ }^{(9)}$

Most of the studies (E02, E03, E04, E05, and E07) compared the effectiveness of the saline solution versus heparin for maintaining CVC-TI patency, showing that there are no significant complications when using the saline solution instead of heparin as a catheter block solution. Thus, it is believed that, for the decision to use the heparinized solution or $0.9 \%$ sodium chloride, a critical analysis based on scientific evidence is necessary, an essential tool for the promotion of quality care and consequent gain of gains in health.

According to the literature, the conclusion that the saline solution is as effective as the heparin solution for maintaining CVC-TI patency seems to be well supported, as it prevents the occurrence of adverse events resulting from the use of heparin, such as thrombocytopenia heparin-induced hemorrhage, among others already mentioned ${ }^{(33)}$
Regarding the dose of heparin necessary to maintain CVC-TI patency, studies E01, E04, E06, E09, $\mathrm{E} 11$, and E12 show that the concentrations ranged from $10 \mathrm{IU} / \mathrm{ml}$ to $5,000 \mathrm{IU} / \mathrm{ml}$, with a predominance of the concentration of $100 \mathrm{IU} / \mathrm{ml}$, with a volume ranging from 3 to $5 \mathrm{ml}$ of the CVC-TI blocking solution.

The dose of heparin required to maintain CVC-TI patency can vary from 10 to $1,000 \mathrm{IU} / \mathrm{ml}$, with the concentration of $100 \mathrm{IU} / \mathrm{ml}$ in a volume of $3 \mathrm{ml}$ being the most commonly used(2,31,22,34). This recommendation corroborates the results of Goossens, et al. 2015, and the recommendations from the Infusion Nursing Society (INS) (2016), which indicate the use of the lowest possible heparin concentration to maintain catheter patency 28,35$)$.

A retrospective cohort study, performed with 2,996 patients with breast cancer, at the Breast Disease Center of the $4^{\text {th }}$ Hospital of the Hebei Medical University in China, used a heparin concentration of $100 \mathrm{IU} / \mathrm{ml}$ to maintain CVC-TI patency, presenting an occlusion rate of $4.3 \%$, with maintenance every 28 days $^{(36)}$.

Although $40 \%$ of the selected studies used $5 \mathrm{ml}$ of the solution as a blocking volume for the CVC-TI and $31 \%$ only $3 \mathrm{ml}$ of the solution, it is important to note that the volume of the block used for maintaining the CVC-TI must be at least two times the prime of the device used in question, 
thus avoiding incomplete filling which, consequently, would increase the risk of obstruction ${ }^{(31,22,35)}$.

In spite of the variation in the solution dose, the CVC-TI reservoir should be considered, which has a dead space and an internal volume larger than a standard catheter. Thus, a volume of $2.5 \mathrm{ml}$ to $3 \mathrm{ml}$ is used to perform the catheter block, so that the amount is slightly higher than the prime of the catheter, considering that the adherence of lipids, fibrin, and other drug deposits to the reservoir wall can result in the colonization of microorganisms and subsequently in bloodstream infection related to the catheter ${ }^{(2,28)}$.

A study carried out in the National Cancer Institute (Instituto Nacional de Câncer, INCA) involving 69 CVC-TI implantations, taking into account the length of the catheter inserted in the patients and the necessary volume of the solution for its filling, found that the volume required for filling the catheter, varies from $0.62 \mathrm{ml}$ to $1 \mathrm{ml}$ and that, according to the INS recommendations, the volume of the filling solution should vary from $1.24 \mathrm{ml}$ to $2 \mathrm{ml}^{(35,37)}$.

Regarding the time interval for maintaining the patency of the device, for studies E03, E05, E09, E10, $\mathrm{E} 11, \mathrm{E} 12$, and E13, an interval of 28 to 56 days was observed. However, it is worth mentioning that it is feasible to extend the CVC-TI maintenance period, without harming the patient, aiming at improving their quality of life and reducing hospital costs.

INS (2017) emphasizes that the CVC-TIs should be washed after each use (infusion of drugs, serum, blood, among others) and, when not in use, the manufacturer's recommendations should be taken into account if the institution does not have an infusion therapy team and/or protocols, or every four weeks, classifying this recommendation as IIIC. It should be noted that studies on the permeability of the CVC-TI are still scarce ${ }^{(38-40)}$.

Several research studies suggest that the monthly maintenance of the CVC-TIs is excessive, inconvenient for patients, and expensive. Thus, some centers have already started the practice of washing the CVC-TIs once every 90 days, when they are not in use, ensuring that they are effective, safe and capable of increasing patient compliance and satisfaction, in addition to reducing costs both for patients and for health care systems ${ }^{(24,41-42)}$.

When using a concentration of $100 \mathrm{IU} / \mathrm{ml}(3 \mathrm{ml})$, seeking to extend the CVC-TI wash interval to 56 to 90 days, there were no changes in relation to catheter obstruction, regarding the maintenance performed every 28 days, presenting an occlusion rate of up to $3 \%^{(24,42)}$.

The maintenance of a CVC-TI has a mean cost of US\$160.00, including time and nursing equipment.
Thus, reducing the number of washes from 12 to 4 times a year would reduce the annual cost from US\$1,920.00 to US $\$ 640.00$. This is without considering time off work, transportation costs, and other logistical expenses incurred by the patient. The considerable reduction in individual costs for patients has an even more significant economic impact when considered at a population level(36).

The Centers for Disease Control and Prevention (CDCs) and the Oncology Nurse Society guidelines provide some evidence of flexibility for the flush, when recommending a heparin solution of $100 \mathrm{IU} / \mathrm{ml}, 5 \mathrm{ml}$ every month or every 6 to 8 weeks, and after each use of the device, but no recommendation regarding the ideal range $\mathrm{e}^{(26,43-44)}$.

With regard to the limitation of this study, a lack of studies within this perspective was identified. This emphasizes the need to conduct clinical trials comparing the use, not only of different doses of heparin with each other, but also the use of physiological solution to maintain CVC-TI patency because, in addition to being free of complications, there is evidence that shows similar efficacy between the physiological solution and the heparin solution in maintaining the patency of the device, visualizing a safe and evidence-based care practice.

\section{Conclusion}

This study allowed us to conclude that the dose of heparin most used to maintain the patency of the totally implanted central venous catheter in cancer patients was $100 \mathrm{UN} / \mathrm{ml}$, with a volume ranging from $5 \mathrm{ml}$ to $3 \mathrm{ml}$ of the heparin solution, being the dose of $10 \mathrm{UN} / \mathrm{ml}$ the lowest dose found in maintenance, with an interval of 28 days between maintenance instances. However, it was possible to identify that there is an interest in extending the device's heparinization interval, in addition to the use of saline solution to maintain this type of catheter.

As a contribution to the care practice, it is believed that this study presents evidence that lower doses of heparin are sufficient to maintain the previous CVC$\mathrm{TI}$, showing that doses higher than $300 \mathrm{UN} / \mathrm{ml}$ are unnecessary, in addition to being able to contribute to the development complications associated with its use, as previously mentioned.

It is important to note that clinical trials have been carried out in order to compare the effectiveness of heparin in relation to the physiological solution for maintaining CVC-TI patency, and have shown similar effects with regard to its obstruction rate, evidencing a field to be explored through new studies that seek to prove the effectiveness of the physiological solution. 


\section{References}

1. Girda E, Phaeton R, Goldberg GL, Kuo D. Extending the interval for port-a-cath maintenance. Modern Chemother. 2013 Oct;2(2):15-8. doi: 10.4236/mc.2013.22003

2. Honório RPP, Caetano JA, Almeida PC. Validation of standard operating procedures in nursing care of patients with totally implanted catheters. Rev Bras Enferm. 2011 Set-Out;64(5):882-9. doi: 10.1590/ S0034-71672011000500013

3. Palese A, Baldassar D, Rupil A, Bonanni G, Capellari Maria $T$, Contessi $D$, et al. Maintaining patency in totally implantable venous access devices (TIVAD): a time-toevent analysis of different lock irrigation intervals. Eur J Oncol Nurs. 2014 Feb;18(1):66-71. doi: 10.1016/j. ejon.2013.09.002

4. Infusion Nurses Society. Infusion nursing standards of practice. J Infus Nurs. [Internet]. 2016 Jan-Feb [cited Sept 10, 2018];39(1S). Available from: http://source. yiboshi.com/20170417/1492425631944540325.pdf

5. Hill J, Broadhurst D, Miller K, Cook C, Dumanski J, Friesen $\mathrm{N}$, et al. Occlusion management guideline for central venous access devices (CVADs). Vasc Access. [Internet]. 2013 [cited Sept 10, 2018];7(Supplement 1). Available from: http://www.improvepicc.com/uploads/5/6/5/0/56503399/ omg_2013_final_revised.pdf

6. Hill SM, Chu HP, Koeglmeier J, Brind J, Turner S, PenfoldForbes $D$, et al. Significant reduction in catheter-related bloodstream infections with taurolidine lock in children treated with intravenous nutrition for 16,000 catheter days. J Pediatr Gastroenterol Nutr. [Internet]. 2011 Mar[cited Sept 10, 2018];52(Supplement 1):E64-5. Available from: http://cvaa.info/en/publications/occlusion-managementguideline-omg

7. Pittiruti $M$, Hamilton $H$, Biffi R, MacFie J, Pertkiewicz $H$, ESPEN. ESPEN Guidelines in Parenteral Nutrition: central venous catheters (access, care, diagnosis and therapy of complications). Clin Nutr. 2009 Aug;28(4):365-77. doi: 10.1016 / j.clnu.2009.03.015

8. Pires NN, Vasques CI. Nurses' knowledge regarding the handling of the totally-implanted venous access device. Texto Contexto Enferm. 2014 Abr-Jun; 23(2):443-50. doi: http://dx.doi.org/10.1590/010407072014000830013

9. Santos EJF, Nunes MMJC, Cardoso DFB, Apóstolo JLA, Queirós PJP, Rodrigues MA. Effectiveness of heparin versus $0.9 \%$ saline solution in maintaining the permeability of central venous catheters: a systematic review. Rev Esc Enferm USP. 2015 Dec;49(6):999-1007. doi: 10.1590/S0080-623420150000600017

10. Klein J, Jepsen A, Patterson A, Reich RR, Mason TM. Flushing effectiveness in managing central venous catheters in patients undergoing blood and marrow transplantation. Clin J Oncol Nurs. [Internet]. 2018 May [cited Sept 10, 2018];22(2):199-202. Available from: https://cjon.ons.org/cjon/22/2/heparin-versusnormal-saline-flushing-effectiveness-managingcentral-venous-catheters

11. Encarnação RMC, Marques P. Permeability of central venous catheter: a systematic literature review. Rev Enf Ref. 2013 Mar;serIII(9):161-9. doi: http://dx.doi. org/10.12707/RIII1298

12. LeeGM,Arepally GM. Heparin-inducedthrombocytopenia. Hematology Am Soc Hematol Educ Program. 2013;2013: 668-74. doi: 10.1182/asheducation-2013.1.668

13. Pavanellia MF, Spitznerb FL. Heparin-induced thrombocytopenia: a literature review. UNOPAR Cient Ciênc Biol Saúde. 2011;13(Esp):325-32. doi: http:// dx.doi.org/10.17921/2447-8938.2011v0n0p\%25p

14. Mendes KDS, Silveira RCCP, Galvão CM. Integrative literature review: a research method to incorporate evidence in health care and nursing. Texto Contexto Enferm. [Internet]. 2008[cited Sept 20, 2018];17(4): 758-64. Available from: http://www.scielo.br/scielo. php?script=sci_arttext\&pid $=$ S0104-07072008000400018 15. Whittemore $\mathrm{R}$, Knafl $\mathrm{K}$. The integrative review: updated methodology. ] Adv Nurs. [Internet]. 2005[cited Sept 20, 2018];52(5):546-53. Available from: https:// www.ncbi.nlm.nih.gov/pubmed/16268861

16. Galvão TF, Pereira MG. Systematic reviews of the literature: steps for preparation. Epidemiol Serv Saude Brasilia. [Internet]. 2014[cited Sept 20, 2018];23(1):183-4. Available from: http://www.scielo. br/pdf/ress/v23n1/2237-9622-ress-23-01-00183.pdf 17. Phillips B, Ball C, Sackett D, Badenoch D, Straus S, Haynes S, et al. Oxford Centre for Evidence-based Medicine - Levels of evidence (March 2009). [Internet]. [cited Sept 20, 2018]. Available from: https://www. cebm.net/2009/06/oxford-centre-evidence-basedmedicine-levels-evidence-march-2009/

18. Santos JGRP, Barbosa FT, Fraga TS. Quality of randomized clinical trials published in the Jornal Vascular Brasileiro. J Vasc Bras. [Internet]. 2011 [citado Sept 20, 2018];10(1):9-16. Available from: http://www.scielo. $\mathrm{br} / \mathrm{pdf} / \mathrm{jvb} / \mathrm{v} 10 \mathrm{n} 1 / \mathrm{v} 10 \mathrm{n} 1 \mathrm{a03.pdf}$

19. Shea BJ, Grimshaw JM, Wells GA, Boers M, Andersson N, Hamel $C$, et al. Development of AMSTAR: a measurement tool to assess the methodological quality of systematic reviews. BMC Med Res Methodol. [Internet]. 2007 [cited Sept 20, 2018];7(10). Available from: https://bmcmedresmethodol.biomedcentral.com/ articles/10.1186/1471-2288-7-10

20. Faggion CM Jr, Listl S, Giannakopoulos NN. The methodological quality of systematic reviews of animal studies in dentistry. Vet ]. [Internet]. 2012[cited Sept 20, 2018];48:140-7. Available from: https:// 
www.researchgate.net/publication/51649084_The_ methodological_quality_of_systematic_reviews_of_ animal_studies_in_dentistry

21. Mataratzis PSR, Accioly E, Padilha PC. Micronutrient deficiency in children and adolescents with sickle cell anemia: a systematic review. Rev Bras Hematol Hemoter. [Internet]. 2010 [cited Sept 20, 2018];32(3):24756. Available from: http://www.scielo.br/scielo. php?script=sci_arttext\&pid=S1516-84842010000300012 22. Dal Molin A, Clerico M, Baccini M, Guerretta L, Sartorello B, Rasero L. Normal saline versus heparin solution to lock totally implanted venous access devices: results from a multicenter randomized trial. Eur ] Oncol Nurs. [Internet]. 2015[cited Oct 10, 2018];19(6):638-43. Available from: https://www.ncbi. nlm.nih.gov/pubmed/25933709

23. Brito ARO, Nishinari K, Saad PF, Saad KR, Pereira MAT, Emídio SCD, et al. Comparison between saline solution containing heparin versus saline solution in the lock of totally implantable catheters. Ann Vasc Surg. [Internet]. 2018 Feb[cited Aug 03, 2018];47:85-9. Available from: https://www.ncbi.nlm.nih.gov/pubmed/28947219

24. Goossens GA. Flushing and locking of venous catheters: available evidence and evidence deficit. Nurs Res Pract. [Internet]. 2015 [cited Oct 10, 2018];2015:985686. Available from: https://www.hindawi.com/journals/ nrp/2015/985686

25. Bertoglio S, Solari N, Meszaros P, Vassallo F, Bonvento $M$, Pastorino $S$, et al. Efficacy of normal saline versus heparinized saline solution for locking catheters of totally implantable long-term central vascular access devices in adult cancer patients. Cancer Nurs. [Internet]. 2012 JulAgo[cited Aug 03, 2018];35(4):E35-42. Available from: https://www.ncbi.nlm.nih.gov/pubmed/22228390

26. Kuo YS, Schwartz B, J Santiago, Anderson PS, Campos AL, Goldberg GL. How often should a port-Acath be flushed? Cancer Invest. [Internet]. 2005 [cited Nov 05, 2018];23(7):582-5. Available from: https:// www.ncbi.nlm.nih.gov/pubmed/16305984

27. Baram A, Majeed G, Abdullah $H$, Subhi A. Heparin versus saline solution for locking of totally implantable venous access port (TIVAP): cohort study of the first Kurdistan series of TIVAP. Adv Lung Cancer. [Internet]. Dec 2014 [cited Aug 03, 2018];3(4):67-74. Available from: https://www.scirp.org/journal/PaperInformation. aspx?PaperID $=51365$

28. Goossens GA, Jérôme $M$, Janssens $C$, Peetermans WE, Fieuws $S$, Moons $P$, et al. Comparing normal saline versus diluted heparin to lock non-valved totally implantable venous access devices in cancer patients: a randomised, non-inferiority, open trial. Ann Oncol. [Internet]. 2013 Jul [cited Nov 05, 2018];24(7):1892-9. Available from: https://www.ncbi.nlm.nih.gov/pubmed/23553060
29. López-Briz E, Ruiz GV, Cabello JB, Bort-Marti S, Carbonell SR, Burls A. Heparin versus $0.9 \%$ sodium chloride intermittent flushing for prevention of occlusion in central venous catheters in adults. Cochrane Database Syst Rev. [Internet]. 2014 Oct [cited Aug 03, 2018];(10):CD008462. Available from: https://www. ncbi.nlm.nih.gov/pubmed/25300172

30. Johansson $E$, Björkholm $H$, Björvell $H$, Acaso $R$, Takolander $\mathrm{R}$, Olofsson $\mathrm{P}$, et al. Totally implantable subcutaneous port system versus central venous catheter placed before induction chemotherapy in patients with acute leukaemia - a randomized study. Support Care Cancer. [Internet]. 2004 Feb [cited Oct 03, 2018];12(2):99-105. Available from: https://www. ncbi.nlm.nih.gov/pubmed/14648310

31. Kefeli U, Dane F, Yumuk PF, Karamanoglu A, Iyikesici $S$, Basaran $G$, et al. Prolonged interval in prophylactic heparin flushing for maintenance of subcutaneous implanted port care in patients with cancer. Eur J Cancer Care. [Internet]. 2009 Mar [cited Oct 10, 2018];18(2):191-4. Available from: https://www.ncbi. nlm.nih.gov/pubmed/19267736

32. Biffi R, De Braud F, Orsi F, Pozzi S, Arnaldi P, Rotmensz $N$, et al. A randomized, prospective trial of central venous ports connected to standard openended or Groshong catheters in adult oncology patients. Cancer. [Internet]. 2001 Sep [cited Aug 03, 2018];1;92(5):1204-12. Available from: https://www. ncbi.nlm.nih.gov/pubmed/11571734

33. Schallom ME, Prentice D, Sona C, Micek ST, Skrupky LP. Heparin or $0.9 \%$ sodium chloride to maintain central venous catheter patency: a randomized trial. Crit Care Med. [Internet]. 2012 [cited Oct 10, 2018];40(6):1820-6. Available from: https://www.ncbi. nlm.nih.gov/pubmed/22488006

34. Rosenthal K. Guarding against vascular site infection. Nurs Manage. [Internet]. 2006 Apr [cited Oct 10, 2018];37(4):54-66. Available from: https://www. ncbi.nlm.nih.gov/pubmed/15545797

35. Infusion Nurses Society. Infusion nursing standards of practice. [Internet]. 2011 Jan-Feb [cited Oct 10, 2018];34(1). Available from: http://www. incativ.es/documentos/guias/INS_Standards_of_ Practice_2011[1].pdf

36. Ma LI, Liu Y, Wang J, Chang Y, Yu L, Geng C. Totally implantable venous access port systems and associated complications: a single-institution retrospective analysis of 2,996 breast cancer patients. Mol Clin Oncol. [Internet]. Mar 2016 [cited Oct 10, 2018];4(3):456-60. Available from: https://www.ncbi.nlm.nih.gov/pmc/ articles/PMC4774414

37. Gomes AR, Sá SPC, Ferreira SCM, Sousa AI. Difference of volumes in solutions for maintenance 
of totally implanted central venous catheter. Rev Enferm UFPE On Line. [Internet]. 2015 [cited Oct 10, 2018];9(9):9152-61. Available from: https://www. redib.org/recursos/Record/oai_articulo1358373difference-volumes-solutions-maintenance-totallyimplanted-central-venous-catheter

38. Infusion Nurses Society. Vascular Access Device (VAD) Management in: Infusion Nursing Standards of Practice. J Infus Nurs. [Internet]. 2017 Jan[cited Oct 10, 2018]; 39(1):68-94, 2017. Available from: http://source.yiboshi. com/20170417/1492425631944540325.pdf

39. Schiffer CA, Mangu PB, Wade JC, Camp-Sorrell D, Cope DG, El-Rayes BF, et al. Central venous catheter care for the patient with cancer: American Society of Clinical Oncology clinical practice guideline. J Clin Oncol. [Internet]. 2013 Abr [cited Oct 10, 2018];31:1357-70. Available from: https://www.ncbi.nlm.nih.gov/pubmed/23460705

40. Sousa B, Furlanetto J, Hutka M, Gouveia P, Wuerstlein $\mathrm{R}$, Mariz J, et al. Central venous access in oncology: ESMO Clinical Practice Guidelines. Ann Oncol. [Internet]. 2015 September [cited Oct 10, 2018];26:152-68. Available from: https://www.esmo.org/Guidelines/Supportiveand-Palliative-Care/Central-Venous-Access-in-Oncology 41. Dal Molin A, Guerretta L, Mazzufero F, Rasero L. The management of totally implanted venous ports in the ambulatory oncologic patient. J Vasc Access. [Internet]. 2009 Jan-Mar [cited Nov 05, 2018];10:226. Available from: https://www.researchgate.net/ publication/24252392_The_Management_of_Totally_ Implanted_Venous_Ports_in_the_Ambulatory_ Oncologic_Patient

42. Odabas H, Ozdemir NY, Ziraman I, Aksoy S, Abali $H$, Oksuzoglu B, et al. Effect of port-care frequency on venous port catheter-related complications in cancer patients. Int J Clin Oncol. [Internet]. 2014 Aug [cited Nov 05, 2018];19:761-6. Available from: https://www. ncbi.nlm.nih.gov/pubmed/23978939

43. Camp-Sorrell D. Access fevice guidelines: recommendations for nursing practice and education.

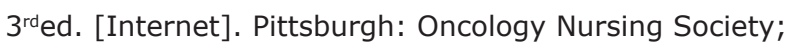
2011. [cited Nov 05, 2018]. Available from: http://www. aqua-guard.com/_documents/AccessDeviceGuidelinesONS-3rdEd.pdf
44. Warren JL, Kamboj M, Sepkowitz KA, Maschmeyer G, Haas A, Guinan JL, et al. Centers for Disease Control and Prevention. Basic infection control and prevention plan for outpatient oncology settings. [Internet]. Dec 2011. [cited Nov 05, 2018]. Available from: https:// www.cdc.gov/hai/pdfs/guidelines/basic-infectioncontrol-prevention-plan-2011.pdf Creative Commons (CC BY).

This license lets others distribute, remix, tweak, and build upon your work, even commercially, as long as they credit you for the original creation. This is the most accommodating of licenses offered. Recommended for maximum dissemination and use of 